\title{
In Hypertension Patients is Diet and Exercise more Effective in Lowering High Blood Pressure Compared to Exercise Alone
}

\author{
Himwaaba Gift ${ }^{1,2}$ \\ ${ }^{1}$ Ph.D. Public Health, Texila American University, Zambia \\ ${ }^{2}$ Zambia Correctional Service, Lusaka Regional Medical Coordinator
}

\begin{abstract}
The objective of this systematic review was to explore ways of using diet and regular exercise as a means of reducing of reducing high blood pressure levels the world over. High blood pressure is fundamentally associated with high morbidity, mortality rates, and disability. Generally, lifestyle modifications such as exercise and a healthy diet have been seen to lower blood pressure in hypertensive and normotensive. A search of the literature was conducted on the Medline database to identify articles related to the research question. We also obtained the primary studies from the reference list of the retrieved review articles. The search was performed using the following key terms combination; hypertension, diet, and exercise, regular exercise, exercise alone, and lowering high blood pressure. For this project, the Medline database was searched under EBSCO host on $29^{\text {th }}$ of April 2013, and there was no restriction on the years covered by the search. A total of eight articles were found to be relevant. Of all these articles reviewed, three addressed the issue of diet, and the other five addressed the issue of exercise as an intervention. Lifestyle modifications using exercise and diet was found to have a great effect in reducing blood pressure in hypertensive patients and normotensive in all the reviewed articles. There is evidence that diet and exercise have a substantial effect in reducing blood pressure in hypertensive patients and the normotensive in all the reviewed articles.
\end{abstract}

Keywords: Diet and Exercise, Exercise alone, Hypertension, Lowering High Blood Pressure.

\section{Introduction}

Hypertension is a disorder marked by an intermittent or sustained elevation of diastolic (90 $\mathrm{mm} \mathrm{Hg}$ or more) or systolic $(140 \mathrm{~mm} \mathrm{Hg}$ or more) blood pressure [1]. Despite people having interest and knowledge on the use of nonpharmacological therapy in managing hypertension, such as exercise and healthy diet, this has not been promoted at a larger scale to the general population at large. This may be due to a lack of agreement or knowledge on the type of diet and exercise to be used. Traditionally, approaches to control the epidemic of high blood pressure-related atherosclerotic cardiovascular disease (ASCVD) have concentrated on drug therapy. Despite this, still, non-pharmacological therapy such as diet and exercise have an important and expanding role [2], to play in the management of hypertension.

\section{Highlights on the Importance of Topic}

The importance of this review is to bring on board cheaper means of managing raised blood pressure such as lifestyle modifications (diet and exercise) the world over. By so doing, there will be a reduced burden of complications due to hypertension and improved quality of life at the national and individual level. Hypertension is also known as high blood pressure, is a global public health issue; it contributes to the burden of heat diseases, stroke, kidney failure [3]. It is also a leading cause of ill health, premature mortality, and disability [4]. Hypertension is a major health problem throughout the world because of its high prevalence and its association 
with increased risk of cardiovascular diseases. Hypertension is also a leading cause of morbidity and mortality among noncommunicable diseases. It has shown a rapid increase in prevalence affecting the urban more than the rural population in sub-Saharan Africa [5]. Hypertension contributes to cardiac and renal failure [6], and it is a major cause of cerebral vascular accidents (CVA) [7]. Cardiovascular diseases are a major cause of disability and premature death throughout the world [8]. Hypertensive disorders of pregnancy are an important cause of sever morbidity, longterm disability, and deaths among both mothers and their babies [9]. Hypertensive disorders of pregnancy account for 12 to $20 \%$ of the total maternal death in the world and other complications such as small for gestational age babies because of impaired growth [10]. Uncontrolled hypertension will result in significant economic costs in addition to the burden of other diseases such as AIDS/HIV, malaria, and tuberculosis [10]. This disease has a severe negative impact on economic development, such as high cost of treatment, limited productivity [11], and the other economic impact of this chronic disease include the cost of illness, individual and family are affected, labor market performance, and human capital accumulation [12]. Treating the complications of hypertension entails reducing costly interventions such as cardiac bypass, carotid artery surgery, and dialysis, which drains individual and government budgets [3]. There are many consequences of hypertension, such as premature death, disability, personal and family disruption, loss of income, and health care expenditure due to this scourge and takes a toll on families, communities, and national finances [3]. If no action is taken to tackle hypertension, the economic losses are projected to outstrip public spending on health [3]. With the researches going on to bring onboard the cheaper means of managing this illness using exercise and diet, we hope to reduce all the related costs of managing this scourge.

\section{Research Papers and Government Documents with Statistical Figures}

There are about 970 million people with elevated blood pressure worldwide, of these, 330 million are in developed countries, and 640 million are in developing countries [3]. In Zambia, hypertension affects all ages and classes and has risk factors that are mainly attributable to lifestyles such as physical inactivity and unhealthy diets [13]. During the past years for the period 2009, 2010, and 2011 hypertension has been the highest cause of visitation among non-communicable diseases to health facilities [13]. Table 1 below shows the number of hypertension patients in relation to the number of non-communicable diseases within this particular period in Zambia 2009-2011.

Table 1. Hypertension Disease for all Age Groups in Zambia for 209 to 2011

\begin{tabular}{|l|l|l|l|l|l|l|l|l|}
\hline \multicolumn{7}{|l|}{ Hypertension disease for all age groups combined in Zambia for 2009 to 2011} \\
\hline All ages 2009 & \multicolumn{7}{|c|}{ All ages 2010 } & All ages 2011 \\
\hline disease & number & $\%$ & disease & number & $\%$ & disease & number & $\%$ \\
\hline hypertension & 101181 & 43 & hypertension & 118549 & 34.8 & hypertension & 144071 & 35 \\
\hline
\end{tabular}

\section{Signs and Symptoms of Hypertension}

Hypertension is called a silent killer, and it is a very serious disease since the symptoms are only known when it becomes serious. If overlooked, it may lead to serious consequences, sometimes even fatal. It is an invisible killer that rarely causes symptoms [3]. Aside from characteristic high blood pressure, hypertension is classified according to its cause, severity, and type; the two major types are essential (also called primary or idiopathic) hypertension, the most common (90\% to $95 \%$ of cases), and secondary hypertension which results from renal 
disease or another identifiable cause [1]. Commonly asymptomatic and the patient is usually unaware that she or he has a disease, raised blood pressure may be discovered on routine medical examination and when complications occur such as a stroke [7]. In severe cases, patients complain of headache, palpitations, dizziness, exertional dyspnea, chest pains, and convulsions [7]. Complications due to hypertension occur late and can attack any organ system such as; cardiac complications due to hypertension occur late and can attack any organ system such as; cardiac complications may include coronary artery disease, angina, myocardial infarction, heart failure arrhythmias, and sudden death; neurologic complications may include cerebral infarctions and hypertensive encephalopathy; hypertension retinopathy can cause blindness, and renal vascular hypertension can lead to renal failure [1]. Other signs and symptoms of hypertension include fatigue, sudden loss of balance, abdominal discomfort due to high congestion in the liver, oliguria due to reduced renal perfusion, peripheral edema, cyanosis, peripheral vasoconstriction, jugular venous distension, systolic murmur in mitral or tricuspid regurgitation can be heard and pulmonary crackles due to fluid transudation, especially pulmonary congestion.

\section{Epidemiological Data}

Prevalence trends and incidence are important epidemiological considerations for hypertension, the leading cause of cardiovascular diseases [14]. Hypertension is prevalent all around the world, with one in three adult's lives with hypertension [11]. The largest deaths due to non-communicable diseases are due to hypertension accounting for $48 \%$ due to the adoption of western lifestyle by people in developing countries, and it is said to have led to a sharp rise in the incidence of hypertension [10]. Hypertension affects more than 60 million adults in the United States of America, blacks are twice as likely as whites to be affected, and they are four times as likely to die of the disorder [1]. In 2008 , worldwide, approximately $40 \%$ of adults aged 25 years and above had been diagnosed with hypertension; the number of people with the condition rose from 600 million in 1980 to 1 billion in 2008, the prevalence of hypertension is highest in the African region at $46 \%$ of adults aged thirty and above, while the lowest prevalence at $35 \%$ is found in the Americans [3]. The increasing prevalence of hypertension is attributed to population growth, aging, and behavioral risk factors, such as unhealthy diet, lack of physical activity [3].

\section{Age, Gender Affected by Hypertension}

Hypertension is associated with identifiable behavioral and biological risk factors such as race, obesity, diabetes, age, sex, alcoholism, sedentary lifestyles, diet (salt), and family history of hypertension [4]. Age is a major risk factor for hypertension, in that blood pressure increases with age in both men and women. Blacks are twice as likely as whites to be affected, and they are four times likely to die of the disorder [1]. Before the age of 55 years, men are more affected with hypertension than women, and after this age, the reverse is true [15]. African Americans are six times more likely to develop end-stage renal disease from hypertension than whites. More than $40 \%$ of African men and women have hypertension and accounts for over $40 \%$ of all death in this group. Hypertension is also becoming more common in children and teenagers, among young people; boys are at higher risk for high blood pressure than girls.

\section{Pathophysiology}

Most cases are idiopathic, and a few cases (less than 5\%) may be caused by other diseases [7]. Increased blood volume, cardiac rate, stroke volume, or arteriolar vasoconstriction that increases peripheral resistance causes blood pressure to rise [1]. Abnormalities in the neurohormonal activation and water and electrolyte balance also play a central role in the cascade that leads from hypertension to heart failure [14]. Angiotensin 2 is an important initiator of extracellular matrix remodeling, 
which contributes to the pathogenesis of atherosclerosis and cardiac hypertrophy [14]. The heightened sympathetic nervous system predisposes to vasoconstriction, sodium retention, and ventricular hypertrophy; the latter occurs as increased noradrenaline release results in myocyte hypertrophy, increased apoptosis of cardiomyocytes, and deficits in cardiomyocyte contractility; these changes are facilitated by B adrenoceptor hyperactivity [14].

\section{Risk Factors}

The risks factors for hypertension include Tobacco use, physical inactivity, unhealthy diet (rich in salt, fat, and calorie), high blood pressure, cholesterol, diabetes, overweight, and stress.

\section{How the Disease is Managed in Practice}

The purpose of treatment is to prevent complications [7]. Management is according to the cause and type of hypertension condition. Blood pressure drugs work in several ways by removing excess salt and fluid from the body, slowing the heartbeat, or relaxing and widening the blood vessels [3].

Although hypertension has no cure, drugs and modifications in diet and lifestyle can control it. Generally, non-drug treatment, such as lifestyle modification, is tried first, especially in early and mild cases [1].

If the diastolic pressure remains above $90 \mathrm{~mm}$ hg despite at least six months of non-drug treatment, monotherapy may begin, thiazide diuretic or a beta-blocker is the drug of choice; initially, this therapy is preferred because studies have demonstrated a decrease in morbidity with this therapy [1].

\section{The General Outcome Measures}

Early detection, lifestyle modifications such as healthy diet and regular exercises play a significant role in better hypertension outcomes. If hypertension is left untreated it causes severe complications such as coronary heart artery disease, angina, myocardial infarction, heart failure, arrhythmias, sudden death, and stroke [1].

\section{The Effects on Patients' Lives}

Cardiovascular diseases are a major cause of disability and premature death throughout the world [8]. Treating the complications of hypertension entails costly interventions such as cardiac bypass, carotid artery surgery, and dialysis, hence draining individual budgets [3]. Premature death, disability, personal and family disruption, loss of income, and health care expenditure due to hypertension take a toll on families, communities [3]. The results of complications due to hypertension have negative impacts on the patient's life, such as reduced quality of life, psychological disturbance, disability, and pain, increased deformity due to stroke, and also sexual disturbances due to erectile dysfunction.

\section{The Significance of this Study}

The major importance of doing this study was to find ways of incorporating diet and exercise in our daily life in order to reduce; high blood pressure, the likely complications, and also to reduce the prevalence and incidence of raised blood pressure.

By introducing diet and exercise as a means of lowering raised blood pressure which is less costly, there is hope to reduce the huge budgets spent on procuring these conventional drugs by governments and the donor community with diet and exercise; there is anticipation that the severe side effects from conventional drugs such as erectile dysfunction would be reduced. Furthermore, the economic consequences and biological uncertainties of long-term pharmacological treatment of hypertensive persons urge that alternative treatments should be examined, such as reduced salt in food and exercising [16].

\section{Objectives of the Study}

The objective of this review was to investigate the effect of diet and exercise as 
interventions on blood pressure in hypertension patients. Specifically, this review aimed;

1. At synthesizing evidence from research papers assessing the effectiveness of healthy diet and exercise in lowering high blood pressure in hypertension patients compared to exercise alone.

2. Discussing how diet and exercise can be developed in order to reduce raised blood pressure in hypertensive patients.

3. At assessing the relationship between exercise and diet with hypertension.

\section{Methodology}

\section{Creating Criteria for Selecting Evidence into this Review}

It has been said that high-quality systematic review should have inclusion criteria that is vigorously and transparently reported so that the search targets articles that will provide answers to the review question, leaving the irrelevant ones [17]. The criteria for selecting these studies followed from the research question and the identified PICO (population, intervention, comparison, and outcome) components [17]. This well-formulated question had key components that were used in the criteria for selecting studies for this review [18]; these key components of interest are population, interventions, comparison, and outcome. The clinical question was "in hypertension patients, is diet and exercise more effective in lowering high blood pressure compared to exercise alone." Since the clinical question was formulated, the next step was to find relevant evidence that would answer the clinical question [19].

The first stage in selecting studies involved the checking of results from electronic search and assessing the titles and abstracts to assess whether they met the predetermined criteria for eligibility [18]. Table 2. Shows articles that were relevant to the aims of the focused question that were also identified by checking the reference list of retrieved articles in order to identify the primary studies.

\section{Types of Studies}

The articles included or that were relevant for this focused question are randomized controlled trial articles because, looking at the hierarchy of evidence, they are said to be the best. The other reason for inclusion is that they were addressing the question to be reviewed [18]. A randomized controlled trial is also exhaustive in addressing a clearly defined question [20].

These should have the population of interest, which is hypertension patients, the intervention of interest, which is diet and exercise, the comparison, which is exercise alone, and the outcome of interest is reduced blood pressure. All the studies that have mentioned the intervention of interest, either diet or exercise, were included in order not to miss some articles that may be relevant, and also in that it may be difficult to find studies that have this type of combination intervention.

\section{Types of Participants or What is the Problem}

Looking at the research question on the population of interest, "hypertension patients," there was no restriction on age, sex, race because hypertension affects all.

\section{Types of Interventions/Issues}

The type of intervention that was of interest in this focused question was all types of diet and exercises. There was no restriction on the type of diet or exercise but a duration of two to fifty-two weeks.

\section{Types of Comparison}

The comparison of interest in this focused question was exercise alone in reducing high blood pressure. All types of exercises were considered duration two to fifty-two weeks.

\section{Types of Outcome Measures}

The desired outcome in this clinical research question was lowering elevated blood pressure or preventing hypertension hence reducing incidences and severity of this disease. The other outcomes of importance that were desired are 
reduced deaths, improved physical and and also improved social-economic outcomes emotional wellbeing, improved quality of life [21].

Table 2. Summary of Inclusion and Exclusion Criteria

\begin{tabular}{|l|l|l|}
\hline & Inclusion & Exclusion \\
\hline Population & All hypertension patients & $\begin{array}{l}\text { All studies that did not include } \\
\text { hypertension patients }\end{array}$ \\
\hline Intervention & All types of diet and exercises & $\begin{array}{l}\text { All studies that did not include } \\
\text { either of the two interventions }\end{array}$ \\
\hline comparison & Exercise alone & $\begin{array}{l}\text { If the method of outcome } \\
\text { assessment were inadequately } \\
\text { described. }\end{array}$ \\
\hline Outcome & Reduced high blood pressure & $\begin{array}{l}\text { Commentaries, review } \\
\text { documents, case studies }\end{array}$ \\
\hline Types of studies & All randomised controlled trials (RCTs) \\
\hline
\end{tabular}

\section{The Search Strategy}

Search strategy was very important so that relevant articles are not omitted [20]. The research question was "in hypertension patients is diet and exercise more effective in lowering high blood pressure compared to exercise alone". Since the search question was in place the next step was to focus on the key components of the question for initial search strategy [18]. Since the clinical question is health related a health-related electronic bibliographic database was searched. The databases used to search were
Medline because they include abstracts for majority of recent records and it is considered as one of the richest sources of trials [18]. Medline is the most widely used database for searching the biomedical literature and it is freely available on the internet, it is also updated regularly and is relatively user friendly [19]. For this project Medline database was searched under EBSCO host on the $29^{\text {th }}$ April 2013, there was no restriction on the years covered by the search [18]. The PICO elements of the focused question are shown in Table 3 below.

Table 3. PICO Elements (Keywords) of the Focused Question

\begin{tabular}{|l|l|l|l|}
\hline Population & Intervention/issue & comparison & Outcome \\
\hline Hypertension patients & diet and exercise & Exercise alone & Lowering high blood pressure \\
\hline
\end{tabular}

Since the PICO elements (keywords) in the focused question have already been identified, these are population (hypertension patients), intervention (diet and exercise), comparison (exercise alone) and outcome (lowering high blood pressure). The next thing was to find relevant evidence to the clinical question [19].

The Table 4 below shows the synonyms to the keywords in the research question.

Table 4. Synonyms to the Key Words

\begin{tabular}{|l|l|l|l|l|}
\hline PIO & $\mathbf{P}$ & $\mathbf{I}$ & $\mathbf{C}$ & $\mathbf{O}$ \\
\hline Keywords & hypertension & Diet and exercise & Exercise alone & Lowering high blood pressure \\
\hline Synonyms & $\begin{array}{l}\text { 1. High blood } \\
\text { pressure patients }\end{array}$ & 1.Food and workout & 1.workout & 1.Reduce hypertension \\
\cline { 2 - 5 } & $\begin{array}{l}\text { 2.Cardiovascular } \\
\text { patients }\end{array}$ & 2.Meals and training & 2.training & 2.Cut cardiovascular disease \\
\hline
\end{tabular}


Since all the synonyms related to keywords in the focused question have been generated, then the keywords and the generated synonyms are combined using Boolean operators "OR" and "AND". Boolean operators AND allows only articles containing both terms to be retrieved, while OR allows articles containing either term to be retrieved [19]. The CINAHL database was used in line with the focused question, which was medical in nature. Boolean operators "AND" and "OR" were used to narrow (specificity) and broaden (sensitivity) the search, respectively.

The ability to search databases effectively is an important aspect of evidence-based research; this is dependent upon a well-focused question and the ability to break it down into PICO terms and finding synonyms.

\section{Assessing the Methodological Quality of the Evidence}

The quality of evidence generated depends on the quality of the primary studies that make up the review [17]. The types of study design for this clinical question are randomized controlled trials. Assessing the methodological quality of the included studies is an important part in evidence-based practice. Since all relevant articles on the subject have been obtained, the next step was to appraise the evidence for its validity and clinical usefulness [19]. The most important component of critical appraisal is an evaluation of the appropriateness of the study design for the research question and careful assessment of key methodological features of the design [22]. The assessment of the validity, both internal validity (the degree to which the study provides valid evidence for the population and setting in which it was conducted) and external validity (the extent to which the evidence is relevant and generalizable to the population and conditions of typical primary care practice) has an important role throughout the process and is evident in the detailed reporting of individual quality items of all included studies. Validity means the extent the research study actually measures that which it is designed to measure. To do all this, several tools are available for appraising different research articles/designs; these are CASP [23]. The tools are simple, easy to use, and freely available on the internet. For this project, randomized controlled trial frameworks were be used; different studies use different frameworks according to research design.

\section{Results}

\section{Search Results}

The number of retrieved articles from the search strategy was eight; all were reviews and from the reference list of these retrieved articles was forty-three. After applying inclusion and exclusion criteria at the title and abstract level, eight articles were identified as relevant. This search was conducted on the Medline database under EBSCO host using keywords and generated synonyms. Only the eight randomized controlled trials from the reference list were included because they were primary studies and had the PICO components of the research question. Table 5 below shows the search results of the included articles.

\section{Summary of the Evidence that has been Included in the Project}

The summary of the evidence included in this project is shown in Table 6 .

\section{Summary of the methodological quality of the evidence}

The methodological quality of all included articles was assessed; these are randomized controlled trials. A critical appraisal skill program scale or tool was used to assess the quality of all the articles that met the inclusion criteria. The methodological quality looks at internal and external validity, reliability, and overall rigor. The (Table 7.) below shows a summary of the methodological quality of included articles. These tools assess the quality of all the articles that met the inclusion criteria. 
Table 5. Search Results, Data Base, Searched and Number of Articles

\begin{tabular}{|c|c|c|c|c|c|}
\hline Data base or method & $\begin{array}{l}\text { Number of articles } \\
\text { found from search }\end{array}$ & $\begin{array}{l}\text { Number of articles } \\
\text { discarded due to } \\
\text { irrelevant title }\end{array}$ & $\begin{array}{l}\text { Number of articles } \\
\text { duplicated from } \\
\text { another database }\end{array}$ & $\begin{array}{l}\text { Number of articles } \\
\text { discarded at abstract }\end{array}$ & $\begin{array}{l}\text { Number of articles to } \\
\text { review by title and abstract }\end{array}$ \\
\hline Medline (EBSCO HOST) & 8 & 1 & 0 & 7 & 0 \\
\hline Checking of the reference list & 43 & 35 & 0 & 0 & 8 \\
\hline
\end{tabular}

Table 6. Summaries of Evidence of the Included Articles in this Review

\begin{tabular}{|c|c|c|c|c|}
\hline Study by & Main aim & method & Main findings & conclusion \\
\hline $\begin{array}{l}\text { Svetkey L.P., } \\
\text { Simons-Morton } \\
\text { D.G., Vollmer } \\
\text { W.M., Appel L.J., } \\
\text { Conlin P.R., Ryan } \\
\text { D.H., Ard J. and } \\
\text { Kennedy B.M., } \\
\text { 1999. }\end{array}$ & $\begin{array}{l}\text { To determine the effects of dietary } \\
\text { patterns on blood pressure in } \\
\text { subgroups. }\end{array}$ & $\begin{array}{l}\text { The study design was a randomised } \\
\text { controlled trial. This was done at four } \\
\text { academic centres. Sample size was } 459 \\
\text { adult hypertensive patients. The sampling } \\
\text { method was by probability sampling } \\
\text { (simple random) computer generated. } \\
\text { Study duration was } 8 \text { weeks. Data } \\
\text { collection method was completing a daily } \\
\text { diary and direct observation. }\end{array}$ & $\begin{array}{l}\text { The combination diet } \\
\text { significantly lowered both } \\
\text { systolic and diastolic in all } \\
\text { subgroups. The DASH diet } \\
\text { lowered systolic blood } \\
\text { pressure significantly more } \\
\text { in African American than in } \\
\text { whites. }\end{array}$ & $\begin{array}{l}\text { The DASH combination diet } \\
\text { may be an effective strategy } \\
\text { for preventing and treating } \\
\text { hypertension across all } \\
\text { population groups. }\end{array}$ \\
\hline $\begin{array}{l}\text { Sacks F.M., Svetkey } \\
\text { L.P., Vollmer W.M., } \\
\text { Appel L.J., Bray } \\
\text { G.A., Harsha D., } \\
\text { Obarzanek E., } \\
\text { Conlin P.R., Miller } \\
\text { Iii E.R., Simons- } \\
\text { Morton D.G., } \\
\text { Karanja N. and Pao- } \\
\text { Hwa Lin, 2001. }\end{array}$ & $\begin{array}{l}\text { The aim was to study the effects of } \\
\text { different levels of dietary sodium } \\
\text { in conjunction with the dietary } \\
\text { approaches to stop hypertension } \\
\text { (DASH) diet which is rich in } \\
\text { vegetables, fruit and low-fat dairy } \\
\text { products in persons with and those } \\
\text { without hypertension. }\end{array}$ & $\begin{array}{l}\text { The study design was randomised } \\
\text { controlled multicentre. Sample size was } \\
412 \text { hypertensive and none hypertensive. } \\
\text { Duration of the study was from September } \\
1997 \text { to November } 1999 \text {. The sampling } \\
\text { method was by simple random. Data } \\
\text { collection method was by questionnaires, } \\
\text { daily food dairies, measuring of } 24 \text { hours } \\
\text { urinary excretion. }\end{array}$ & $\begin{array}{l}\text { Reduction in sodium intake } \\
\text { significantly lowered } \\
\text { systolic and diastolic blood } \\
\text { pressure both in the control } \\
\text { and DASH diet. }\end{array}$ & $\begin{array}{l}\text { Reduction of sodium intake to } \\
\text { levels below the current } \\
\text { recommendation of } 100 \mathrm{mmol} \\
\text { per day and the DASH diet } \\
\text { both lower blood pressures } \\
\text { substantially, with greater } \\
\text { effects in combination than } \\
\text { singly. }\end{array}$ \\
\hline
\end{tabular}




\begin{tabular}{|c|c|c|c|c|}
\hline $\begin{array}{l}\text { Margetts B.M., } \\
\text { Berlin L.J., } \\
\text { Vandongen R. and } \\
\text { Armstrong B.K., } \\
1986 .\end{array}$ & $\begin{array}{l}\text { Was to examine the effects of a } \\
\text { vegetarian diet in subjects with } \\
\text { mild hypertension and also to as } \\
\text { nearly as possible the diet of long- } \\
\text { term vegetarians. }\end{array}$ & $\begin{array}{l}\text { Randomised trial of } 58 \text { hypertension } \\
\text { patients aged } 30 \text { to } 64 \text { years. Duration six } \\
\text { weeks. Sampling method was simple } \\
\text { random. Data collection method was } \\
\text { dietary records, standiometer for height, } \\
\text { weight using beam scale, questionnaires } \\
\text { were completed }\end{array}$ & $\begin{array}{l}\text { There was fall in blood } \\
\text { pressure in vegetarian diet of } \\
\text { about } 5 \mathrm{~mm} \text { hg in untreated } \\
\text { subjects with hypertension. }\end{array}$ & $\begin{array}{l}\text { The study has shown that in } \\
\text { untreated subjects with mild } \\
\text { hypertension, changing to } \\
\text { vegetarian diet may bring } \\
\text { about a worthwhile fall in } \\
\text { systolic blood pressure. }\end{array}$ \\
\hline $\begin{array}{l}\text { Moreira W.D., } \\
\text { Fuchs F.D., } \\
\text { Lawrence J., Iberia } \\
\text { J.P. and Appel, } \\
\text { 1999. }\end{array}$ & $\begin{array}{l}\text { The main aim was to assess the } \\
\text { effect of six months of resistance } \\
\text { or endurance exercise training on } \\
\text { blood pressure in health } 70-79 \\
\text { years old men and women with } \\
\text { normal and elevated blood } \\
\text { pressure. }\end{array}$ & $\begin{array}{l}\text { The design was randomised controlled } \\
\text { trial. Location was at the hypertension unit } \\
\text { of the hospital de Clinicas de Ponto } \\
\text { Alegre. The sample size was } 28 \text { sedentary } \\
\text { hypertension patients; the duration was ten } \\
\text { weeks physical training. Sampling method } \\
\text { was probability sampling. Data collection } \\
\text { method was recording heart rate and blood } \\
\text { pressure from particular measuring } \\
\text { instruments. }\end{array}$ & $\begin{array}{l}\text { Across all participants, a } \\
\text { reduction in systolic blood } \\
\text { pressure was significant. }\end{array}$ & $\begin{array}{l}\text { The conclusion is that aerobic } \\
\text { training programs at } 20 \% \text { and } \\
60 \% \text { of the maximum work } \\
\text { capacity have similar effects } \\
\text { on ambulatory blood pressure. }\end{array}$ \\
\hline $\begin{array}{l}\text { Cononie C.C., } \\
\text { Graves J.E., Pollock } \\
\text { M.L., Philips M.I., } \\
\text { Sumners C., and } \\
\text { Hagberg J.M. } 1991 .\end{array}$ & $\begin{array}{l}\text { The main aim was to assess the } \\
\text { effect of six months of resistance } \\
\text { or endurance exercise training on } \\
\text { blood pressure in health } 70-79 \\
\text { years old men and women with } \\
\text { normal and elevated blood } \\
\text { pressure. }\end{array}$ & $\begin{array}{l}\text { Design was randomised controlled trial. } \\
\text { Sample size was } 56 \text { male and female. } \\
\text { Duration was six months. Sampling } \\
\text { method was by stratified random. Data } \\
\text { collection method was by objectively } \\
\text { measuring using different instruments such } \\
\text { as random-zero sphygmomanometer. }\end{array}$ & $\begin{array}{l}\text { Endurance exercise training } \\
\text { produces modest reduction } \\
\text { in blood pressure in } 70-79 \\
\text { years old individuals. }\end{array}$ & $\begin{array}{l}\text { It appears that healthy men } \\
\text { and women in their seventies } \\
\text { with moderate hypertension } \\
\text { can lower their blood pressure } \\
\text { with endurance exercises to } \\
\text { the same degree as can young } \\
\text { and middle-aged hypertensive. }\end{array}$ \\
\hline $\begin{array}{l}\text { Martin J.E., Dubbert } \\
\text { P.M. and Cushman } \\
\text { W.C., 1990. }\end{array}$ & $\begin{array}{l}\text { To determine the antihypertensive } \\
\text { efficacy of aerobic exercise } \\
\text { training in mild essential } \\
\text { hypertension. }\end{array}$ & $\begin{array}{l}\text { This was a randomised controlled trial } \\
\text { crossover. This was done at an outpatient } \\
\text { research clinic in a university-affiliated } \\
\text { veteran's administration medical centre. } \\
\text { Sample size was } 27 \text { men with untreated }\end{array}$ & $\begin{array}{l}\text { The study provides evidence } \\
\text { for the independent } \\
\text { antihypertensive effect of } \\
\text { aerobic exercise in mildly }\end{array}$ & $\begin{array}{l}\text { This study demonstrates that } \\
\text { moderate aerobic exercise } \\
\text { lowers blood pressure in } \\
\text { hypertensive subjects and } \\
\text { might be an important }\end{array}$ \\
\hline
\end{tabular}




\begin{tabular}{|c|c|c|c|c|}
\hline & & $\begin{array}{l}\text { diastolic blood pressure of } 90 \text { to } 104 \text {. } \\
\text { Duration was } 10 \text { weeks sampling method } \\
\text { was simple random. Data collection } \\
\text { method was by objectively measuring by } \\
\text { different instruments such as random-zero } \\
\text { sphygmomanometer. }\end{array}$ & $\begin{array}{l}\text { essential hypertensive men } \\
\text { who were not on medication. }\end{array}$ & $\begin{array}{l}\text { modality in the control of } \\
\text { hypertension. }\end{array}$ \\
\hline $\begin{array}{l}\text { Gunjal S., Shinde } \\
\text { N., Kazi A. and } \\
\text { Khatri S., } 2013\end{array}$ & $\begin{array}{l}\text { The aim was to study the effect of } \\
\text { aerobic interval training on blood } \\
\text { pressure and myocardial function } \\
\text { in hypertensive patients. }\end{array}$ & $\begin{array}{l}\text { The design was an experimental (pre-post) } \\
\text { design. Location of the study was at } \\
\text { department of cardiorespiratory } \\
\text { physiotherapy pravara rural hospital, loni, } \\
\text { India. Participants were } 30 \text { hypertensive } \\
\text { patients. Duration of the study was } 12 \\
\text { weeks. Sampling method was non- } \\
\text { probability. Data collection method by B } \\
\text { mode images was recorded and by } \\
\text { modified biplane Sampson's method. }\end{array}$ & $\begin{array}{l}\text { There was significant } \\
\text { reduction in blood pressure } \\
\text { and there was improvement } \\
\text { in ejection fraction, stroke } \\
\text { volume, cardiac output and } \\
\text { peripheral resistance } \\
\text { decreased by } 17 \% \text { after } \\
\text { aerobic interval training. }\end{array}$ & $\begin{array}{l}\text { The study indicates that } \\
\text { aerobic interval training is } \\
\text { effective to reduce blood } \\
\text { pressure and heart rate and } \\
\text { improves myocardial function } \\
\text { in hypertensive patients and } \\
\text { that moderate to high intensity } \\
\text { of the three weekly bouts of } \\
\text { interval training for } 12 \text { weeks } \\
\text { reduced blood pressure and } \\
\text { improved cardiac function. }\end{array}$ \\
\hline $\begin{array}{l}\text { Liu S., Goodman J., } \\
\text { Nolan R., Shawn } \\
\text { L.S. and Scott G., } \\
2012 .\end{array}$ & $\begin{array}{l}\text { The main aim was to assess the } \\
\text { relation between the degrees of } \\
\text { post exercise hypotension with } \\
\text { acute exercise and also to examine } \\
\text { the correlates of blood pressure } \\
\text { reduction after chronic exercise in } \\
\text { both sexes. }\end{array}$ & $\begin{array}{l}\text { The design was quasi experimental study } \\
\text { we are told the study benefited from a } \\
\text { longitudinal study design. Location was at } \\
\text { university of Toronto athletic centre. } 17 \\
\text { participant's duration } 8 \text { weeks. Sampling } \\
\text { method was non-probability. Data } \\
\text { collection method questionnaires were } \\
\text { completed, training was recorded in a } \\
\text { weekly log. }\end{array}$ & $\begin{array}{l}\text { Blood pressure was } \\
\text { significantly reduced relative } \\
\text { to the baseline after } 30 \\
\text { minutes of acute and chronic } \\
\text { exercises. }\end{array}$ & $\begin{array}{l}\text { The magnitude of the acute } \\
\text { blood pressure lowering with } \\
\text { exercise may predict the extent } \\
\text { of blood pressure lowering } \\
\text { after chronic training } \\
\text { intervention in } \\
\text { prehypertension individual and } \\
\text { that lifestyle intervention and } \\
\text { in particular chronic aerobic } \\
\text { exercises may prevent or delay } \\
\text { the development of } \\
\text { hypertension. }\end{array}$ \\
\hline
\end{tabular}


Table 7. Summaries of Methodological Quality of Included Articles

\begin{tabular}{|c|c|c|c|c|}
\hline Study by & Internal validity & External validity & reliability & Overall rigour \\
\hline $\begin{array}{l}\text { Svetkey L.P., Simons- } \\
\text { Morton D.G., Vollmer } \\
\text { W.M., Appel L.J., } \\
\text { Conlin P.R., Ryan D.H., } \\
\text { Ard J. and Kennedy } \\
\text { B.M., } 1999 .\end{array}$ & $\begin{array}{l}\text { Was high due to random allocation of } \\
\text { participants, similarity of groups at } \\
\text { baseline, computer generated random } \\
\text { allocation, blinding of staff, } \\
\text { concealment of allocation, data } \\
\text { analysis was done on an intention to } \\
\text { treat analysis, control of variables, } \\
\text { adequacy of follow ups, data collection } \\
\text { methods through questionnaires, } \\
\text { observation and completed dairies. }\end{array}$ & $\begin{array}{l}\text { High due to the following sample } \\
\text { size was } 459 \text {, probability sampling } \\
\text { method, cluster eligibility was } \\
\text { followed, acceptability of } \\
\text { intervention, outcome measures } \\
\text { were considered such as change in } \\
\text { systolic and diastolic blood } \\
\text { pressure, exclusion and inclusion, } \\
\text { power analysis. The article did not } \\
\text { mention anything on dropout. }\end{array}$ & $\begin{array}{l}\text { High due to use of } \\
\text { standard tools such as } \\
\text { random zero } \\
\text { sphygmomanometer, data } \\
\text { analysis instruments such } \\
\text { as SAS software package. }\end{array}$ & $\begin{array}{l}\text { Strong due to } \\
\text { intervention and } \\
\text { intended } \\
\text { outcome. }\end{array}$ \\
\hline $\begin{array}{l}\text { Sacks F.M., Svetkey } \\
\text { L.P., Vollmer W.M., } \\
\text { Appel L.J., Bray G.A., } \\
\text { Harsha D., Obarzanek } \\
\text { E., Conlin P.R., Miller } \\
\text { Iii E.R., Simons-Morton } \\
\text { D.G., Karanja N. and } \\
\text { Pao-Hwa Lin, 2001. }\end{array}$ & $\begin{array}{l}\text { High due to random allocation of } \\
\text { participants, concealment of allocation, } \\
\text { blinding of participants and dietary } \\
\text { staff, similarity of groups at baseline, } \\
\text { intention to treat analysis, adequacy of } \\
\text { follow ups, data collection (diaries and } \\
\text { questionnaires) methods, statistical } \\
\text { analysis and there was control of } \\
\text { variables. }\end{array}$ & $\begin{array}{l}\text { High due to sample size of } 412 \\
\text { participants, probability sampling } \\
\text { method, cluster eligibility } \\
\text { (exclusion and inclusion), cluster } \\
\text { generalizability, outcome of } \\
\text { systolic and diastolic blood } \\
\text { pressure. The study did not } \\
\text { mention anything on dropouts, and } \\
\text { acceptability of intervention and } \\
\text { power analysis. } \\
\end{array}$ & $\begin{array}{l}\text { High due to the use of } \\
\text { standard tools such as } \\
\text { random zero } \\
\text { sphygmomanometer. }\end{array}$ & strong \\
\hline $\begin{array}{l}\text { Margetts B.M., Berlin } \\
\text { L.J., Vandongen R. and } \\
\text { Armstrong B.K., } 1986 .\end{array}$ & $\begin{array}{l}\text { High due to control of variables, } \\
\text { random allocation, concealment of } \\
\text { allocation, similarity of groups at } \\
\text { baseline, intention to treat analysis, } \\
\text { adequacy of follow ups, data collection } \\
\text { methods such as questionnaires, }\end{array}$ & $\begin{array}{l}\text { High due to sample size } 58 \\
\text { participants, probability sampling } \\
\text { method, cluster eligibility } \\
\text { (exclusion and inclusion), cluster } \\
\text { generalizability, outcome of } \\
\text { interest, dropouts were taken care. } \\
\text { Though there is no mention of }\end{array}$ & $\begin{array}{l}\text { High due to use of } \\
\text { standard tools such as } \\
\text { standard mercury } \\
\text { sphygmomanometer, } \\
\text { automatic oscillometric } \\
\text { device, specialist } \\
\text { physicians, stadiometer }\end{array}$ & strong \\
\hline
\end{tabular}




\begin{tabular}{|c|c|c|c|c|}
\hline & $\begin{array}{l}\text { statistical analysis. But blinding was } \\
\text { not done. }\end{array}$ & $\begin{array}{l}\text { acceptability of intervention, } \\
\text { power analysis. }\end{array}$ & $\begin{array}{l}\text { for height, beam scale for } \\
\text { weight and auto analyser }\end{array}$ & \\
\hline $\begin{array}{l}\text { Liu S., Goodman J., } \\
\text { Nolan R., Shawn L.S. } \\
\text { and Scott G., } 2012 .\end{array}$ & $\begin{array}{l}\text { Low because there is no blinding, } \\
\text { random allocation, concealment of } \\
\text { allocation, intention to treat analysis. } \\
\text { The other things were taken into } \\
\text { consideration such as control of } \\
\text { variables, similarity of groups at } \\
\text { baseline, adequacy of follow ups, data } \\
\text { collection methods (questionnaires and } \\
\text { recording), and statistical analysis. }\end{array}$ & $\begin{array}{l}\text { High due to sample size } 17 \\
\text { participants using power } \\
\text { calculation, outcome of interest } \\
\text { was systolic and diastolic blood } \\
\text { pressure, follow ups adequate all } \\
\text { completed (no drop out) the study, } \\
\text { cluster eligibility, cluster was } \\
\text { done. The sampling method was } \\
\text { non-probability. There is no } \\
\text { mention on acceptability of } \\
\text { intervention. }\end{array}$ & $\begin{array}{l}\text { High due to use of } \\
\text { standard tools, such as } \\
\text { heart rate monitor watch, } \\
\text { automated oscillometric } \\
\text { brachial blood pressure } \\
\text { device, applanation } \\
\text { tonometry for arterial } \\
\text { stiffness and finometer } \\
\text { MIDI MODEL-2 for } \\
\text { blood pressure beats, } \\
\text { ANOVA was used for } \\
\text { evaluation and automated } \\
\text { sphygmomanometer for } \\
\text { brachial blood pressure. }\end{array}$ & Slightly weak \\
\hline $\begin{array}{l}\text { Gunjal S., Shinde N., } \\
\text { Kazi A. and Khatri S., } \\
2013\end{array}$ & $\begin{array}{l}\text { Low due to none blinding, no } \\
\text { concealment of allocation, no random } \\
\text { allocation, intention to treat analysis } \\
\text { not mentioned, statistical analysis not } \\
\text { done. Others were done such as } \\
\text { similarity of groups at baseline, } \\
\text { adequacy of follow ups, data collection } \\
\text { method and control of variables. }\end{array}$ & $\begin{array}{l}\text { Low due to sample size, sampling } \\
\text { method non-probability, cluster } \\
\text { generalizability not mentioned, } \\
\text { and acceptability of intervention } \\
\text { not mentioned, power analysis was } \\
\text { not done. Cluster eligibility was } \\
\text { done, outcome, exclusion and all } \\
\text { these were done. }\end{array}$ & $\begin{array}{l}\text { High due to use of } \\
\text { standard tools, such as } \\
\text { karvonen's formula for } \\
\text { exercise intensity, } \\
\text { sphygmomanometer for } \\
\text { blood pressure, pulse } \\
\text { oxymeter for heart rate, } \\
\text { modified biplane } \\
\text { Sampson's method for } \\
\text { ejection fraction and } \\
\text { echocardiography was } \\
\text { done by experienced }\end{array}$ & Slightly weak \\
\hline
\end{tabular}




\begin{tabular}{|c|c|c|c|c|}
\hline & & & $\begin{array}{l}\text { cardiologist using vivid } 7 \\
\text { scanner with m35 probe }\end{array}$ & \\
\hline $\begin{array}{l}\text { Martin J.E., Dubbert } \\
\text { P.M. and Cushman } \\
\text { W.C., } 1990 .\end{array}$ & $\begin{array}{l}\text { High due to blinding, control of } \\
\text { variables, random allocation, } \\
\text { concealment of allocation, similarity of } \\
\text { groups at baseline, adequacy of follow } \\
\text { ups, data collection methods. These } \\
\text { others are not mentioned, statistical } \\
\text { analysis, and intention to treat analysis. }\end{array}$ & $\begin{array}{l}\text { High due to sample size, sampling } \\
\text { method inclusion (probability), } \\
\text { cluster eligibility, dropouts, } \\
\text { exclusion and inclusion criteria. } \\
\text { These others are not mentioned } \\
\text { cluster generalizability, } \\
\text { acceptability of intervention, } \\
\text { outcome, and power analysis. }\end{array}$ & $\begin{array}{l}\text { High due to use of } \\
\text { standard tools such as } \\
\text { random zero } \\
\text { sphygmomanometer, } \\
\text { specialist nurse assessed } \\
\text { the blood pressure, and } \\
\text { ANOVA was used to } \\
\text { analyse variance. }\end{array}$ & strong \\
\hline $\begin{array}{l}\text { Cononie C.C., Graves } \\
\text { J.E., Pollock M.L., } \\
\text { Philips M.I., Sumners } \\
\text { C., and Hagberg J.M. } \\
\text { 1991. }\end{array}$ & $\begin{array}{l}\text { High due to, control of variables, } \\
\text { random allocation, concealment of } \\
\text { allocation, similarity of groups at } \\
\text { baseline, though there is no mention of } \\
\text { intention to treat analysis, adequacy of } \\
\text { follow ups, data collection methods, } \\
\text { statistical analysis and blinding. }\end{array}$ & $\begin{array}{l}\text { High due to sample size } 56 \\
\text { participants, sampling method } \\
\text { (probability), cluster eligibility, } \\
\text { dropouts accounted, exclusion and } \\
\text { inclusion used. Cluster } \\
\text { generalizability, acceptability of } \\
\text { intervention, outcome, and power } \\
\text { analysis are not mentioned. }\end{array}$ & $\begin{array}{l}\text { High due to use of } \\
\text { standard tools such as } \\
\text { random zero } \\
\text { sphygmomanometer, and } \\
\text { computerised collier co2 } \\
\text { rebreathing technique for } \\
\text { cardiac output. }\end{array}$ & strong \\
\hline $\begin{array}{l}\text { Moreira W.D., Fuchs } \\
\text { F.D., Lawrence J., Iberia } \\
\text { J.P. and Appel, } 1999 \text {. }\end{array}$ & $\begin{array}{l}\text { High due to blinding, control of } \\
\text { variables, random allocation, } \\
\text { concealment of allocation, similarity of } \\
\text { groups at baseline, intention to treat } \\
\text { analysis, statistical analysis, though } \\
\text { adequacy of follow ups, data collection } \\
\text { methods are not mentioned. }\end{array}$ & $\begin{array}{l}\text { High due to sample size of } 28 \\
\text { participants, sampling method } \\
\text { (probability), cluster eligibility, } \\
\text { exclusion and inclusion. Cluster } \\
\text { generalizability, acceptability of } \\
\text { intervention, outcome, dropouts, } \\
\text { and power analysis are not } \\
\text { mentioned. }\end{array}$ & $\begin{array}{l}\text { High due to use of } \\
\text { standard tools such as } \\
\text { model PIV device for } \\
\text { blood pressure and } \\
\text { treadmill for physical } \\
\text { fitness. }\end{array}$ & strong \\
\hline
\end{tabular}




\section{Synthesis of the Main Findings from the Evidence}

All the studies have shown that lifestyle modifications such as diet and exercise lowered blood pressure in hypertensive patients.

Table $8 \mathrm{a}$ shows the reduction of blood pressure in different types of exercise. In Moreira et al. mean 24 hours systolic blood pressure fell from 137.2 plus or minus 14.9 to 135 plus or minus $12.7 \mathrm{~mm} \mathrm{Hg}$, and the mean diastolic blood pressure fell from 92.1 plus or minus 10.0 to 89.3 plus or minus $7.7 \mathrm{~mm} \mathrm{Hg}$. In Cononie et al. the reduction in blood pressure in the endurance training group initial systolic blood pressure was 139 plus or minus 16, diastolic 81 plus or minus $8 \mathrm{~mm} \mathrm{Hg}$ and after six- month blood pressure fell to systolic 135 plus or minus 17, diastolic 76 plus or minus $7 \mathrm{~mm} \mathrm{Hg}$. In martin et al., blood pressure was reduced from systolic $136.6 \mathrm{~mm} \mathrm{Hg}$ and diastolic $94.8 \mathrm{~mm} \mathrm{hg}$ to systolic $130.1 \mathrm{~mm} \mathrm{Hg}$ and diastolic $85.2 \mathrm{~mm}$ Hg. In Gunjal et al., blood pressure reduced from systolic 152 plus or minus $12 \mathrm{~mm} \mathrm{Hg}$ and diastolic 96 plus or minus $8 \mathrm{~mm} \mathrm{Hg}$ to systolic 140 plus or minus $12.5 \mathrm{~mm} \mathrm{Hg}$ and diastolic 84 plus or minus $8 \mathrm{~mm} \mathrm{Hg}$. In Lui et al. blood pressure reduced from systolic 126 plus or minus $1.8 \mathrm{~mm} \mathrm{Hg}$ and diastolic 81 plus or minus 1.1 $\mathrm{mm} \mathrm{Hg}$ to systolic 120 plus or minus $1.8 \mathrm{~mm} \mathrm{Hg}$ and diastolic 75 plus or minus $1 \mathrm{~mm} \mathrm{Hg}$. Overall, there is a trend of reduced blood pressure from high to lower levels.

Table 8a. Below Pre and Post Exercise Intervention Blood Pressure Levels of Each Study

\begin{tabular}{|l|l|l|l|l|l|}
\hline \multicolumn{2}{|l|}{} & \multicolumn{2}{l|}{ Before intervention } & \multicolumn{2}{l|}{ After intervention } \\
\hline Study by & intervention & systolic & diastolic & systolic & diastolic \\
\hline $\begin{array}{l}\text { Cononie et al } \\
1991 .\end{array}$ & $\begin{array}{l}\text { Endurance } \\
\text { exercise }\end{array}$ & $\begin{array}{l}139 \pm 16 \mathrm{~mm} \\
\mathrm{Hg}\end{array}$ & $\begin{array}{l}81 \pm 8 \mathrm{~mm} \\
\mathrm{Hg}\end{array}$ & $\begin{array}{l}135 \pm 17 \mathrm{~mm} \\
\mathrm{Hg}\end{array}$ & $76 \pm 7 \mathrm{~mm} \mathrm{hg}$ \\
\hline $\begin{array}{l}\text { Martin et al } \\
1990\end{array}$ & $\begin{array}{l}\text { Aerobic } \\
\text { exercise }\end{array}$ & $\begin{array}{l}136.6 \mathrm{~mm} \\
\mathrm{Hg}\end{array}$ & $\begin{array}{l}94.8 \mathrm{~mm} \\
\mathrm{Hg}\end{array}$ & $130.1 \mathrm{~mm} \mathrm{hg}$ & $85.2 \mathrm{~mm} \mathrm{Hg}$ \\
\hline $\begin{array}{l}\text { Moreira et al } \\
1999\end{array}$ & $\begin{array}{l}\text { Physical } \\
\text { training } \\
\text { exercise }\end{array}$ & $\begin{array}{l}137.2 \pm 14.9 \\
\mathrm{~mm} \mathrm{Hg}\end{array}$ & $\begin{array}{l}92.1 \pm 10 \\
\mathrm{~mm} \mathrm{Hg}\end{array}$ & $\begin{array}{l}135.2 \pm 12.7 \\
\mathrm{~mm} \mathrm{Hg}\end{array}$ & $\begin{array}{l}89.3 \pm 7.7 \mathrm{~mm} \\
\mathrm{Hg}\end{array}$ \\
\hline $\begin{array}{l}\text { Gunjal et al } \\
2013\end{array}$ & $\begin{array}{l}\text { Aerobic interval } \\
\text { training } \\
\text { exercise }\end{array}$ & $\begin{array}{l}152 \pm 12 \mathrm{~mm} \\
\mathrm{Hg}\end{array}$ & $\begin{array}{l}96 \pm 8 \mathrm{~mm} \\
\mathrm{Hg}\end{array}$ & $\begin{array}{l}140 \pm 12.5 \\
\mathrm{~mm} \mathrm{Hg}\end{array}$ & $84 \pm 8 \mathrm{~mm} \mathrm{Hg}$ \\
\hline $\begin{array}{l}\text { Liu et al } \\
2012\end{array}$ & $\begin{array}{l}\text { Acute and } \\
\text { chronic aerobic } \\
\text { exercises }\end{array}$ & $\begin{array}{l}126 \pm 1.8 \\
\mathrm{~mm} \mathrm{Hg}\end{array}$ & $\begin{array}{l}81 \pm 1.1 \\
\mathrm{~mm} \mathrm{Hg}\end{array}$ & $\begin{array}{l}120 \pm 1.8 \\
\mathrm{~mm} \mathrm{Hg}\end{array}$ & $75 \pm 1 \mathrm{~mm} \mathrm{Hg}$ \\
\hline
\end{tabular}

Table $8 \mathrm{~b}$ shows different types of diets and there lowering effect on blood pressure. In Svetkey et al. the DASH diet significantly lowered systolic and diastolic blood pressure by $11.4 \mathrm{~mm} \mathrm{Hg}$ in all subgroups $\mathrm{p}=0.03$. In Sacks et al. DASH and low sodium lowered blood pressure by $11.5 \mathrm{Hg}$ in hypertensive patients $\mathrm{p}<0.001$. In Margetts et al. the fall in blood pressure following a vegetarian diet was $5 \mathrm{~mm}$ Hg $\mathrm{p}<0.05$. 
Table 8b. Pre and Post Diet Intervention Blood Pressure Levels of Each Study

\begin{tabular}{|l|l|l|l|l|l|l|}
\hline \multicolumn{2}{|l|}{} & \multicolumn{2}{|l|}{ Before intervention } & \multicolumn{2}{l|}{ After intervention } & \\
\hline Study by & Intervention & Systolic & Diastolic & Systolic & Diastolic & P value \\
\hline $\begin{array}{l}\text { Svetkey et al } \\
1999\end{array}$ & DASH diet & $160 \mathrm{~mm} \mathrm{Hg}$ & $95 \mathrm{~mm} \mathrm{Hg}$ & $148.6 \mathrm{~mm} \mathrm{Hg}$ & $83 \mathrm{~mm} \mathrm{Hg}$ & $\mathrm{P}=0.03$ \\
\hline $\begin{array}{l}\text { Sacks et al } \\
2001\end{array}$ & $\begin{array}{l}\text { DASH plus } \\
\text { sodium diet }\end{array}$ & $134 \mathrm{~mm} \mathrm{Hg}$ & $86 \mathrm{~mm} \mathrm{Hg}$ & $122.5 \mathrm{~mm} \mathrm{Hg}$ & $\begin{array}{l}74.5 \mathrm{~mm} \\
\mathrm{Hg}\end{array}$ & $\mathrm{P}<0.001$ \\
\hline $\begin{array}{l}\text { Margetts et } \\
\text { al 1986 }\end{array}$ & $\begin{array}{l}\text { Ovolactovegetarian } \\
\text { diet }\end{array}$ & $\begin{array}{l}154.4 \mathrm{~mm} \\
\mathrm{Hg}\end{array}$ & $\begin{array}{l}98.5 \mathrm{~mm} \\
\mathrm{Hg}\end{array}$ & $149.4 \mathrm{~mm} \mathrm{Hg}$ & $\begin{array}{l}93.5 \mathrm{~mm} \\
\mathrm{Hg}\end{array}$ & $\mathrm{P}<0.05$ \\
\hline
\end{tabular}

\section{Discussion}

\section{Summary of Key Findings}

There is good evidence from all the identified articles. All the included studies have identified diet and exercise as a means to reduce or lower blood pressure. Though the articles included did not exclusively just discuss on exercise and diet, it was one of the areas of study interest. Nevertheless, all the articles touched on the condition of interest, which is hypertension. It has been noted that hypertension patients greatly benefit from diet and exercise, lowering the effect on blood pressure. The treatment effect of exercise and diet on hypertensive patients was substantial. These lifestyle modifications (diet and exercise) have been highly recommended in these included studies.

Although the included articles in this review seem to have been of short duration, they seem to have been intensive studies because most of these were relevant to issues of long-term sustainability, which is of prime importance in clinical practice and in determining the public health impact of the studies considered.

\section{Interpretation of Key Findings}

Most of the findings were in line with the main objective, which is 'to investigate the effect of diet and exercise interventions on blood pressure in hypertension patients. The problem of validity makes it difficult to make firm conclusions on the basis of the articles considered and makes it probable that the findings reported are overestimates of the effect that might be achieved in practice.

The randomized controlled trials evidence was good though there was no study that looked at the intervention of interest the way it appears in the research question. In this review, the intervention of interest is diet and exercise, but most articles retrieved looked at either diet or exercised singly. All the randomized controlled trial included in this review was relevant to the research question and were of good methodological quality. Randomized controlled trials were explicit, reproducible and up to date. They were conducted in an explicit and wellstructured methodology which minimized the possibility of bias. Some of these studies were not explicit and were not well structured methodologically, which brought in the possibility of bias. Despite these shortcomings these studies had important information relevant to the research question and objective.

\section{Finding on Objective One}

Objective number one was 'to synthesize evidence from research papers assessing the effectiveness of healthy diet and exercise in lowering high blood pressure in hypertension patients compared to exercise alone'. In relation to this objective, all the included studies have evidence to support the use of diet and exercise as a means of lowering high blood pressure. The evidence was found in all the eight included articles. In all these articles, reduction in blood pressure was significant. 


\section{Findings on Objective Two}

Objective two was 'to discuss how a healthy diet and exercise and can be developed in order to reduce raised blood pressure in hypertensive patients. This means of lowering blood pressure is reasonably priced, low risk, and easily implementable. DASH diet includes most of the readily available foods, which are well accepted in most populations. The estimate of cost places the DASH diet between low-cost and moderatebased foods. High and moderate exercise have been seen to have the same effect on blood pressure as such, it has been recommended as a safe and efficacious intervention.

\section{Findings on Objective Three}

The last objective was on the assessment of the relationship between exercise and a healthy diet with hypertension. In all the five articles on exercise as an intervention means of lowering blood pressure, the effect has been seen even in chronic and acute exercises. Whether high or low-intensity trainings, the blood pressurelowering effect was substantial. It also found that a vegetarian diet lowered blood pressure in untreated subjects with mild hypertension. Even when other factors were held constant, the DASH diet lowered blood pressure. Foodless in sodium significantly lowered blood pressure in both control and DASH diets.

\section{Limitations of the Study}

The major limitations of this review were that none of these included articles looked at diet and exercise combined as an intervention and then comparing it with exercise alone. This search may also have been limited by none usage of truncation and wildcat symbol. If this search was to be repeated, efforts would be made to find all variant spellings and also variant endings (plural or singular) in order to increase sensitivity. The other limitation was that the confounding factors in other studies were not taken care of; hence they may have altered the outcome of interest. The other limitation is that most of these studies were of short duration.

\section{Implications and Application to Practice of the Study}

All the included articles showed a lot of factors and results that can be applied since most important factors that are related to individual and policy were considered where it might contribute to change the policy and practice. There is an acknowledgement that conventional treatment has done little to reduce the number of patients with hypertension. The research has found an alternative to reducing high blood pressure, such as lifestyle modifications (diet and exercise). Emphasis is now being placed on efficient and cost-effective strategies for diagnosing and managing hypertensive patients. Recent evidence from most studies indicates that non-pharmacological therapy, which includes dietary potassium and calcium supplements, reduction of salt intake, regular exercise, a diet high in fibre and low in cholesterol and saturated fats, produces a significant reduction in blood pressure. In most of the studies, salt restriction and increased physical activity are generally accepted lifestyle measures in the management of hypertension. In the studies that involved physical activities, the reduction in blood pressure was not related to the intensity of the exercises. The dietary approaches to stop hypertension (DASH) diet is also highly recommended in most of the studies done, and it was very effective in reducing blood pressure in both hypertensive and non-hypertensive. In line with the objectives of this study, it has been seen that diet and exercise play a major role in high blood pressure reduction.

\section{Indication for Further Research}

One of the areas that need further consideration is the sample size (should be bigger to be able to generalize the findings); longer duration for the research, also there is a need to reduce confounding factors. There is a need to assess the long-term safety, use, and acceptability of the intervention by communities. Most of these researches were done at higher-level centers, and there is a need 
to go to lower-level communities who are not taped. There is also a need to look at how exercise and diet impact on the quality of life and mortality rates.

\section{Recommendations}

Recommendations such as to eat well and exercise are generally safe and inexpensive and likely to have desired benefits. Most of the articles have recommended the use of diet and exercise in lowering high blood pressure. Most research on dietary approaches to stop hypertension (DASH) combination diet, which contains large amounts of fruit, vegetables, fish and nuts, low-fat dairy products, and reduced levels of total and saturated fat, together with exercise, have been effective in lowering high blood pressure. First, all stakeholders, both in government and individuals, must put in more effort to tap knowledge on the issue of exercise and diet for the management of hypertensive patients. This, I believe, could be done by educating practitioners and teaching them how to document exercise and diet in their practice.

It is important that all medical practitioners are introduced to this new research development in order to have standard health care that cut across all board. It is worth noting that the differences between pharmacological and none pharmacological are not necessarily anything but the way they are used. In recognizing the scientific aspects of exercise and diet, one needs to be cautious of not relegating conventional aspects of the practice. Patients with elevated blood pressure should follow a weight-reducing diet and also take regular exercises and restrict salt intake.

Just as various measures have been put in place by the governments to enhance the services of conventional medicine, attention must be also be given to exercise and diet. Budgetary allocations must much match that of a conventional system. Government must enhance efforts by scaling up the use of exercise and diet. In so doing, the government must put ineffective regulatory bodies to periodically check the works of these health posts.

I'm absolutely in support of advocacy for the use of exercise and diet; I think such an idea will not be bad at all considering the fact that many people use exercise and diet in their daily lives. It is imperative for people to realize that exercise and diet have been in our daily practices. Therefore, it is crucial for one to separate diet and exercise from our daily lives.

Integrating exercise and diet into the national health care policy of Zambia would be an action in the right direction. There must therefore be a much stronger national policy and regulatory framework on issues pertaining to safety, efficacy, quality, access, and rational use of diet and exercise.

Diet and exercise may treat and cure diseases that are currently leading to humans' potential extinction. If actions are taken soon to study and protect this new means of treating hypertension, these lifestyle modifications may find themselves to be the best means of reducing hypertension.

\section{Conclusions}

For a long time, people have lived with the impression that only conventional medicines can treat hypertension; it is time we consider such viewpoints once more. These studies have shown that diet and exercise can holds a vibrant role in the dispensation of good health practices the world over. Most of these studies have acknowledged the potency and prospects of using exercise and diet even with the presence of conventional medicine. It is evident from these studies that diet and exercise can be an alternative, not just complementing conventional medicine.

From the studies, it is clear that exercise and diet will reach one $100 \%$ usage among hypertensive patient; as such, clinicians should come together and fashion ways of enhancing the use of exercise and diet to reduce high blood pressure. Again, since diet and exercise play a central role in the general life of many people, it 
is important for the health systems to embrace this in its practices since there is empirical evidence to support its relevance to indigenous healing. Therefore, if there would be a comprehensive medical system world over, exercise and diet must find its way into practice.

\section{Acknowledgement}

I would like to take this opportunity to thank Dr. Nyanzi Lawrence of Teesside University UK for the guidance he rendered during my writing

\section{References}

[1] Springhouse, PA: Springhouse Corporation, (Eds.) (1992). Diseases, Nursing. Pp. 538-542 Retrieved from https://archive.org/details/diseases00spri.

[2] Appel, L, J., (1999). Nonpharmacologic therapies that reduce blood pressure: a fresh perspective. Clin Cardiol. 1999 Jul; 22(7 Suppl): III1-5. DOI: 10.1002/clc.4960221502. PMID: 10410298 ; PMCID: PMC6655381.

[3] WHO, World Health Day, (2013). A global brief on hypertension: silent killer, global public health crisis: World Health Day, (2013) WHO Reference Number: WHO/DCO/WHD/2013.2

https://www.who.int/publications/i/item/a-globalbrief-on-hypertension-silent-killer-global-publichealth-crisis-world-health-day-2013.

[4] Goma, F. M., Nzala, S. H., Babaniyi, O., Songolo, P., Zyaambo, C., Rudatsikira, E., Siziya, S., \& Muula, A. S. (2011). Prevalence of hypertension and its correlates in Lusaka urban district of Zambia: a population-based survey. International archives of medicine, 4, 34. retrieved from https://doi.org/10.1186/1755-7682-4-34.

[5] Mweene, M., Banda, J., Andrews, B., Mweene, M., Lakhi, S. (2010). Factors Associated with Poor Medication Adherence in Hypertensive Patients in Lusaka, Zambia. Medical Journal of Zambia, 37(4), 252-261. Retrieved from https://www.mjz.co.zm/index.php/mjz/article/view/3 78.

[6] Soudarssanane, M. B., Karthigeyan, M., Stephen, S., Sahai, A. (2006). High Blood Pressure/ up this review. Finally, I would also like to thank my family for giving me space to complete my project and also for providing me with unfailing support and continuous encouragement throughout the process of researching and writing this review.

\section{Conflict of Interest}

Himwaaba Gift declares no conflict of interest.

Hypertension in Adolescents Key Predictors of High Blood Pressure and Hypertension among Adolescents: A Simple Prescription for Prevention. Indian Journal of Community Medicine Vol. 31, No. 3, July - September 2006 164. Retrieved from https://www.ijcm.org.in/temp/IndianJCommunityMe d313164-2472491_065204.pdf.

[7] Ministry of Health and Central Board of Health, (2002). Integrated Technical Guidelines for Frontline Health Workers. 2nd Edition, Ministry of Health and Central Board of Health, Lusaka. Pp. 198-199.

[8] World Health Organization. (2007). Prevention of cardiovascular disease: pocket guidelines for assessment and management of cardiovascular risk: (WHO/ISH cardiovascular risk prediction charts for the European Region). World Health Organization. Retrieved from https://apps.who.int/iris/handle/10665/43784.

[9] World Health Organization, (2011). WHO recommendations for prevention and treatment of pre-eclampsia and eclampsia. Retrieved from https://www.guidelinecentral.com/summaries/whorecommendations-for-prevention-and-treatment-ofpre-eclampsia-and-eclampsia/\#section-society.

[10] Chowa, P. E., Lin, C., Goma, F., South-Paul, J. (2011). Prevalence of Hypertension among Women of Child-Bearing Age in Zambia. Medical Journal of Zambia, 38(3), 3-8. Retrieved from https://www.mjz.co.zm/index.php/mjz/article/view/3 92.

[11] Siziya, S., Rudatsikira, E., Babaniyi, O., Songolo, P., Mulenga, D., et al. (2012) Prevalence and Correlates of Hypertension among Adults Aged 
25 Years or Older in a Mining Town of Kitwe, Zambia. J Hypertens 1:105. DOI: 10.4172/21671095.1000105.

[12] Suhrcke, M., Nugent, R. A., Stuckler, D., Rocco, L. (2006). Chronic Disease: An Economic Perspective London: Oxford Health Alliance 2006 ISBN 0-9554018-1-X. retrieved from www.oxha.org. Chronic-disease-an-economic-perspective.pdf (who.int).

[13] Ministry of Health Global Fund (GF), (2011). Annual Health Statistical Bulletin. Directorate of Policy \& Planning Monitoring \& Evaluation Unit Haile Sellaise Avenue Ndeke House P.O. Box 30205 Lusaka, Zambia. Retrieved from https://www.moh.gov.zm/docs/reports/2011_Annual _Health_Bulletin_\%20FINAL\%20VERSION.pdf.

[14] Georgiopoulou, V. V., Kalogeropoulos, A. P., Butler, J. (2012). Heart failure in hypertension: prevention and treatment. Drugs. $2012 \mathrm{Jul}$; 72(10):1373-1398. DOI: $\quad 10.2165 / 11631100$ 000000000-00000.

[15] Khosh, F., Khosh, M. (2001) Natural approach to hypertension. Altern Med Rev. 2001 Dec; 6 (6):590600. PMID: 11804549. Retrieved from https://pubmed.ncbi.nlm.nih.gov/11804549/.

[16]Wilcox, R. G., Bennett, T., Brown, A. M., Macdonald, I. A. (1982). Is exercise good for high blood pressure? British Medical Journal (Clinical Research ed.). 1982 Sep; 285(6344):767-769. DOI: 10.1136/bmj.285.6344.767.

[17] Bettany-Saltikov J., (2010). Learning how to undertake a systematic review: part 1 . Nurs Stand. 2010 Aug 18-24; 24(50):47-55; quiz 56. DOI: 10.7748/ns2010.08.24.50.47.c7939. PMID: 20865948.
[18] Higgins, J. P. T., Green, S. (2006). Cochrane Handbook for Systematic Reviews of Interventions. In: The Cochrane Library, Issue 4, 2006. Chichester, UK: John Wiley \& Sons, Ltd. Retrieved from https://training.cochrane.org/handbook/archive/v4.2. 6.

[19] Akobeng AK., (2005). Principles of evidencebased medicine. Arch Dis Child. 2005 Aug; 90(8):837-40. DOI: 10.1136/adc.2005.071761. PMID: 16040884; PMCID: PMC1720507.

[20] Abalos E, Carroli G, Mackey ME, Bergel E., (2001). Critical appraisal of systematic reviews: The WHO Reproductive Health Library, No 4, Geneva, The World Health Organization, (WHO/RHR/01.6). Retrieved from http://www.ijsr.ir/files/site1/files/4Critical_appraisal _of_systematic_reviews.pdf.

[21] Ramsay, J., Carter, Y., Davidson, L., Dunne, D., Eldridge, S., Feder, G., Hegarty, K., Rivas, C., Taft, A., Warburton, A. (2009). Advocacy interventions to reduce or eliminate violence and promote the physical and psychosocial wellbeing of women who experience intimate partner abuse. Cochrane Database Syst Rev. 2009 Jul 8; (3): CD005043. DOI: 10.1002/14651858.CD005043.pub2. Update in: Cochrane Database Syst Rev. 2015; 12:CD005043. PMID: 19588364.

[22] Young, J., Solomon, M. (2009). How to critically appraise an article. Nat Rev Gastroenterol Hepatol 6, 82-91 (2009). Retrieved from https://doi.org/10.1038/ncpgasthep1331.

[23]Public Health Resource Unit, England, (2006). Critical appraisal skill program (CASP). Retrieved from

http://cfkr.dk/images/file/CASP20instrumentet.pdf. 